\title{
pro.posições
}

$e$-ISSN 1980-6248

http://dx.doi.org/10.1590/1980-6248-2019-0072EN

ARTIGOS

\section{The Elos Program for drug abuse prevention: repercussions in the daily life of schools ${ }^{12}$}

\author{
O Programa Elos para prevenção do abuso de drogas: \\ repercussões no cotidiano escolar
}

\section{El Programa Elos para la prevención del abuso de drogas: repercusiones en la vida diaria de la escuela}

(i) Universidade de São Paulo - Faculdade de Saúde Pública, São Paulo, SP, Brasil. https://orcid.org/0000-0002-3339-4478, eduardo.caron@usp.br.

(ii) Universidade de São Paulo - Instituto de Psicologia, São Paulo, SP, Brasil. adrimarcon@uol.com.br.

Resumo
Discutem-se repercussões da implementação do Programa Elos de prevenção ao
uso abusivo de drogas (Ministério da Saúde, 2013-2017) quanto à alteração de
relações de assujeitamento, isolamento e desrespeito presentes no cotidiano escolar.
Acompanhou-se em três escolas da região metropolitana de São Paulo a
implementação do programa que é uma parceria entre professores e profissionais
da saúde na realização de um jogo entre equipes de alunos. Foram realizados cinco
grupos focais e nove entrevistas individuais com professores, profissionais de saúde,
coordenadores pedagógicos e gestores de escola; e 20 grupos com oito a dez alunos
de seis a oito anos de idade por grupo. A análise qualitativa deu visibilidade a
mudanças nas relações institucionais intensificadas por práticas de grupalidade,
repactuação permanente e por processos de implicação de si - de professores e de
alunos - instaurados pela prática do jogo, com efeitos sobre a ampliação da potência
para aprender.
Palavras-chave: jogo, grupo, relações, prevenção, saúde

\footnotetext{
${ }^{1}$ Responsible Editor: Carmen Lúcia Soares - carmenls@unicamp.br. https://orcid.org/0000-0002-4347-1924

2 Normalization, preparation, and Portuguese review: Luan Maitan - revisao@tikinet.com.br
} 


\title{
pro.posıções \\ $e$-ISSN 1980-6248
}

http://dx.doi.org/10.1590/1980-6248-2019-0072EN

\begin{abstract}
We discuss repercussions of the implementation of the Elos Program for the prevention of drug abuse (Ministério da Saude, 2013-2017) regarding the alteration of processes of subjection, isolation and disrespect present in school daily life. In three schools in the metropolitan area of São Paulo we followed the implementation of the Program - a partnership between teachers and health professionals to organize a game between teams of students. Five focus groups and nine individual interviews were conducted with teachers, health professionals, pedagogical coordinators, and school administrators; and 20 group meetings with eight to ten students from six to eight years of age each group. The qualitative analysis gave visibility to changes in the institutional relations intensified by group practices, permanent renegotiation, and by processes of implication of oneself - teachers and students - established by the practice of the game, with effects on the amplification of the power to learn.
\end{abstract}

Keywords: game, group, relationships, prevention, bealth

\section{Resumen}

Se discuten las repercusiones de la implementación del Programa Elos de prevención al uso abusivo de drogas (Ministerio de Salud, 2013-2017) en cuanto a la alteración de relaciones de sujeción, aislamiento y falta de respeto en el cotidiano escolar. En tres escuelas de la región metropolitana de São Paulo se acompaño la implementación del Programa - una asociación entre profesores y profesionales de la salud en la realización de un juego entre equipos de alumnos. Se realizaron cinco grupos focales y nueve entrevistas individuales con maestros, profesionales de la salud, coordinadores pedagógicos y gerentes escolares; y 20 grupos con ocho a diez estudiantes de seis a ocho años cada grupo. El análisis cualitativo dio visibilidad a cambios en las relaciones institucionales intensificadas por la práctica del juego - grupalidad, renegociación permanente y por procesos de implicación de profesores y alumnos - con efectos sobre la potencia para aprender.
\end{abstract}

Palabras-clave: juego, grupo, relaciones, prevención, salud

\section{Introduction}

In this article we discuss data from a qualitative study on the experience of implementing the Elos Program within elementary schools in the São Paulo metropolitan area. The aim is to investigate the associations between the application of the Elos Program, implemented on a national scale by the Ministry of Health between 2013 and 2017 in the public health and education network, and possible alterations regarding relationships of subjection, isolation, and disrespect in the daily life at school. The Elos Program was created and implemented from the perspective of a public policy for preventing abuse of alcohol and other drugs. We highlight the 


\section{pro.posıções \\ $e$-ISSN 1980-6248}

importance of analyzing the effects that are produced in the relationships and the collectives in school when implementing a school-based prevention program that focuses on relational fields, forms of conduct, and relationships of force in the collectives established with basis on the program's practices. In this sense, this study does not evaluate the relationship between program implementation and prevention, nor does it problematize concepts of drug abuse.

The fact that this is a school prevention program on the use of alcohol and other drugs set within the sphere of public policies places the study in a complex biopolitical scenario. The theme of prevention has its invention and production of meanings outlined by a historical trajectory that constitutes a field of forces in which the lives of populations become the object of public health policies (Foucault, 1988). In the last three centuries, the expansion of these policies has produced mechanisms of social normalization that amplify the medicalization of life, implementing concepts of normality, pathology, risk, and parameters of health and safety in a variety of social spheres (Caron, 2019; Zorzanelli, Ortega, \& Bezerra, 2014). Produced within this field of forces, the methodologies of prevention constitute procedures that interfere in ways of life and implement subjectivation-objectivation processes.

In the interface between technologies of domination over the other and technologies of subjectivation, Foucault (2004) proposes the concept of governmentality, highlighting the preoccupation with one's own conduct, linked to the forces of disciplinary and regulatory conduct. The invention of the psychological (Figueiredo, 2007), based on different modern thought matrixes, produced a framework of knowledge and practices for handling conduct, embodied in the processes of governmentalization in the family, in school, at work, in organizations, in the media etc., largely disseminated during the $20^{\text {th }}$ century (Carvalho, 2015; Rose, 1999). With these governmentalization processes in mind, Aquino (2009) criticizes, within the educational field, humanist projects for improving people based on techniques for managing this psychological interiority, which indicates the need to consider the analysis of forms of management present in prevention programs. In this work, we will analyze some of these forms.

The Elos Program was created within the sphere of prevention policies that relate to the use of psychoactive drugs in Brazil. After the beginning of the $21^{\text {st }}$ century, there is a rise in the production of research, governmental guidelines (Abramovay \& Castro, 2005; Brasil, 2000), and academic work addressing the theme from a perspective of reduction of risks and damage (Passos \& Souza, 2011). The spectrum broadens for propositions dealing with drug prevention 


\section{pro.posições \\ $e$-ISSN 1980-6248}

http://dx.doi.org/10.1590/1980-6248-2019-0072EN

that do not veer into abstinence (Guerra \& Clark, 2010; Machado \& Boarini, 2013). From this perspective, comprehension of the multiplicity of uses for psychoactive substances is connected to the several forms of human experience. This is not about prevention of drug use, but about preventing conditions that produce damage and favor other horizons and subjectivation processes.

According to reports by the World Health Organization (United Nations Office on Drugs and Crime, 2015) on international experiences within this complex field of production of evidence about prevention, the programs that stand out are those in schools working with children and youths that propose expanding personal and social relational abilities, along with actions that include parents and community. Thus, the European program Unplugged (Vadrucci et al., 2016) and the North American Good Behavior Game (Kellan et al., 2014) were adopted by the Brazilian Ministry of Health, in partnership with the United Nations Office on Drugs and Crime, having been elected among the methodologies that had produced results considered favorable to prevention - according to the criteria mentioned above - in the international arena. The two programs underwent a field-tested cultural adaptation (Medeiros et al., 2016; Peres, Grigolo, \& Schneider, 2016; Scheneider, 2016) that produced the Brazilian versions \#Tamojunto and Elos, which were first implemented in the country between 2013 and 2014.

Both programs had a logical-operational design based on the coordination between municipal health and education departments and the technical team from the Ministry of Health. This interaction produced the planning of intervention locations, training schedules, monitoring, and evaluation. National multipliers from the Ministry of Health facilitated the training of teachers and health workers in order to create a body of multipliers and implementers for each neighborhood containing a Primary Care Center and school. This body of teachers and health workers met regularly for further training, process assessment, and action planning, carrying out a support role so that teachers could implement the programs with their students. From 2013 to 2016, the programs underwent a process of construction of this mechanism within a growing yet restricted number of schools (Table 1), distributed nationally, and which served as field experience for implementation and for validation studies. 


\section{pro.posıções \\ $e$-ISSN 1980-6248}

Table 1 - National Reach of the Elos and \#Tamojunto programs, from 2013 to 2017

Elos Program

\begin{tabular}{ccccc}
\hline Year & Schools & Pupils & Municipalities & States \\
\hline 2013 & 6 & 677 & 4 & 2 \\
2014 & 21 & 1875 & 8 & 5 \\
2015 & 41 & 2601 & 15 & 3 \\
2016 & 62 & 6327 & 8 & 4 \\
2017 & - & - & 11 & 5
\end{tabular}

Tamojunto Program

\begin{tabular}{ccccc}
\hline Year & Schools & Pupils & Municipalities & States \\
\hline 2013 & 8 & 1790 & 3 & 2 \\
2014 & 71 & 7925 & 11 & 7 \\
2015 & 185 & 19577 & 21 & 7 \\
2016 & 178 & 13394 & 8 & 5 \\
2017 & 96 & 9007 & 7 & 5
\end{tabular}

Source: Coordenação Geral de Saúde Mental, Álcool e Outras Drogas - CGMAD. Departamento de Ações Programáticas Estratégicas - DAPES. Secretaria de Atenção à Saúde - SAS, Ministério da Saúde. Histórico de implementação (2013-2017) - Programas de prevenção escolar e comunitário do uso de álcool e outras drogas. Brasília, DF, 2017. Programa Elos - Relatório de Implementação, monitoramento e transferência de tecnologia de 2013-2018. Brasília, DF, 2019.

The programs had two elements: one of working with families — themed meetings with fathers, mothers, and reference adults — and a school element, where students actively took part as the protagonists of group processes, and teachers took sideline positions, as facilitators. The \#Tamojunto Program, aimed at youths between 13 and 15 years of age, focused on discussions about family, groups, society, forms of existence, desires, and feelings. The Elos Program, the subject of this article, dealt with students between six and ten years of age, dividing them into teams that carried out regular activities scheduled in the school curriculum that took the shape of a rule-based game called Elos.

\section{Elements of the daily life in schools that make up the problem for the study}

In this study we have analyzed the effects of the experiment with the Elos Program relating to the elements presented by school educators, principals, vice-principals, and coordinators during the training stage for program implementation. During the discussion 


\section{pro.posıções \\ $e$-ISSN 1980-6248}

http://dx.doi.org/10.1590/1980-6248-2019-0072EN

moments held at these training sessions, the educators criticized the school environment, characterizing it as tiring, noisy, and full of conflict, lacking in cooperation and respect, where voices are not heard and attention is hard to come by, in addition to the high demands upon educators for control over students and upon the administration for control over educators. They affirmed that they were overwhelmed. One component of this feeling of being overwhelmed was generated by the incessant pedagogical projects and specific departmental programs which had started and been discontinued throughout the years without ever coming to an end, producing a sensation of fatigue. The educators also felt pressured by official indexes of school performance and by the demands of administrators regarding the issues highlighted by these indexes. John Mac Beath (cited by Kruppa, Caramelo, \& Terrasêca, 2015) states that this pressure on schools that are submitted to external assessment based on student testing is a global issue, where the value of an educator's experience is disregarded. Principals, pedagogic coordinators, and educators describe their work at school as a stressful race to reach targets where they receive guidelines and training, yet feel isolated and alone in managing the day-today in school. Kruppa (2015) analyzes this condition of subjection at work for teachers who, without being allowed time to evaluate and review their experiences, become more led than leaders.

These elements — the lack of cooperation and voice, isolation, subjection, and disrespect - involved students and teachers and appeared within the scenes narrated by the educators throughout the study. The implementation of the Elos Program presented itself, in this scenario, as an opportunity to act upon these issues, reorganizing some of the forces at play, as a "possibility of fracturing the focuses of experience that impede other derivations of knowledge and practice that are not those already institutionalized" (Carvalho, 2014, p. 112). With an interest in analyzing some of these reorganizations in the relationships in the daily life of schools, in this article we will dwell on the implementation of the program and the monitoring of the Elos game in three municipal elementary schools in the municipality of Taboão da Serra, within the São Paulo metropolitan area, between 2016 and 2017.

\section{The Elos game}

The proposal for the Elos game seeks to promote collective participation in regular curricular activities, carried out in groups or teams, according to a set of game rules which refer to conduct. Lasting 10 to 30 minutes, the game has four basic rules, detailed and agreed upon 


\section{pro.posıções \\ $e$-ISSN 1980-6248}

http://dx.doi.org/10.1590/1980-6248-2019-0072EN

at the start of each match: i) type of mobility that the students may have during the activity: stationary (red), limited mobility (yellow), and free mobility (green); ii) volume levels they may reach during the activity: silence, whispering, group voice, presentation, and street voice; iii) be respectful and kind; iv) carry out the activity. Not calling upon the teacher or requiring their mediation is the main rule of the game, and the students are requested to resolve as a team all relational needs or those pertaining to execution of the task.

The teacher organizes groups of five to seven students who are not friends or habitual partners, balancing teams in terms of performance for task execution. Internally, the teams are heterogeneous: the teacher distributes boys and girls, those who talk more or less, the quieter and more energic children, those who have more or less ease in completing tasks, etc.

Each team has a Guardian, who speaks for the group, elected by the teacher from among those who do not normally occupy leadership positions in class. The aim of the game is to carry out the task as a team while avoiding breaking the rules that were agreed upon. Rule breaking is determined by the teacher, and teams win the match if they have up to four fouls, earning the right to choose a weekly prize - a game, a movie, a collective snack — to be enjoyed by the entire class. Thus, several teams can win.

\section{Method}

For this study we have adopted as analytical reference and outline for field procedures the cartography method as defined by Passos, Kastrup and Escóssia (2009). More than describing the state of things, we consider that this study produces change in a field where there are reciprocal implications for the actors in this situation, and that this change is accompanied by movements of differentiation created by the game/study, in which the participantsresearchers construct moments and strategies to analyze the experience. The actions organized during this research - construction of teams and of discussion spaces - create analytical situations and territories in which the researchers are part of the very processes being monitored.

The place of the teacher or health professional, as simultaneously researcher and implementer of the program's actions, is situated within the process of a participative study in which research management is shared, both in terms of procedures and intervention, and regarding analysis. Bearing in mind the interference - notorious in all branches of scientific 


\section{pro.posıções \\ $e$-ISSN 1980-6248}

research - of the researcher upon the results, the cartographic approach sides with this inseparability between researcher and field of study. In this study, therefore, the teachers and health professionals who implement the actions were not informants or participants of a research carried out by others. They were, rather, the producers, managers, and analysts of the processes for a collective and communal study, favoring the permeability of this research regarding the collective processes being studied. Another consequence is that the relationships and the ways of seeing, feeling, and behaving of the actors change throughout the experiment, and these displacements have implications upon the study, so that the implication of the researchers - teachers and professionals from the local primary care centers - constitutes the object of the study.

Both authors of this article accompanied the implementation of the Elos Program in the Taboão da Serra county in 2014 and 2015. One of them was the program's coordinator for the Municipal Health Department, while the other was invited to consult during the process.

In addition to the authors of the article, the research team was composed of seven teachers, one vice-principal, and two pedagogic coordinators from three municipal elementary schools, as well as four health professionals from primary care centers in the municipality of Taboão da Serra (SP). The investigation was based on the interest of these professionals, who were involved in implementing the program, in analyzing its effects.

The main fields of research were: monitoring the practice of the Elos game in the classroom; carrying out meetings for monitoring and evaluation; and groups with students:

i. Monitoring, by health professionals, of the practice of the Elos game carried out by teachers - this took place once or twice a week, in seven $2^{\text {nd }}, 3^{\text {rd }}$, and $4^{\text {th }}$ grade classes, in three schools located on the outskirts of the municipality where there is greater social vulnerability, which gather between 500 and 700 students from $1^{\text {st }}$ to $5^{\text {th }}$ grade of elementary school each. In total, 70 game matches were monitored in class, involving 210 pupils.

ii. 40 periodic meetings were carried out, denominated monitoring meetings, between one of the teachers and a participating health professional, who would observe the game in the classroom and then evaluate with the teacher the process and problemsituations with the aim of coming up with strategies for the game's evolution. 


\section{pro.posições \\ $e$-ISSN 1980-6248}

http://dx.doi.org/10.1590/1980-6248-2019-0072EN

iii. Four monthly meetings were held with the study's participants - health professionals and teachers from the three schools — for the evaluation and sharing of experiences.

iv. 20 group meetings were held with eight to ten students, lasting between 15 and 20 minutes, where exercises were carried out that explored the imagination, speculating about "Planet Elos". In this space the students produced narratives about their experiences participating in Elos, as well as contributing qualitative analyses and meanings for the experience.

v. A second sphere of research refers to the execution of five discussion meetings and nine unstructured individual interviews with teachers, health professionals, pedagogic coordinators, and school administrators. These conversations and interviews took place at the beginning and at the end of the study.

The researchers kept notes on the observations, the monitoring meetings, the groups, and the interviews. The data was primarily analyzed by systematizing scenes, situations of monitored processes, and experience narratives. Next, these systematizations were discussed by the research team at monthly meetings.

At the end of the process of data production and analysis, a text was created with a consolidated narrative of the entire experience. This narrative was the object of debate at two assemblies with the health and education professionals, generating a final report which was discussed at a municipal meeting with participation by health and education professionals: teachers, school administrators, administrators from the municipal departments of health and education, and guests from the Institute of Psychology of the University of São Paulo.

\section{Results}

The observations, individual conversations, and group meetings allowed the development of different lines of analysis on the alteration of some of the elements present in the daily life of schools by implementation of the Elos game.

As we will see, the Elos game produced experiences of autonomy. At the same time, it also created situations of punitive functioning and of exclusion relating to the practices of 


\section{pro.posições \\ $e$-ISSN 1980-6248}

normalizing contexts of the institutions. The game, when understood as a strategy, brought up for analysis the everyday school issues that had previously emerged during the training sessions carried out for implementation of the program.

Two lines of analysis were defined, relating some of the processes that took place during the Elos game to educational practices present in everyday school life: i) Education as a collective plane of permanent renegotiation; ii) The experience of playing: the implication of oneself and the potential for learning. These lines bring consistency to elements present during the implementation of Elos, highlighting some of the forces involved in the effects of the game in the daily life of schools.

\section{Education as a collective plane of permanent renegotiation}

The experience of the game in the classroom setting, involving students and teacher, demonstrated the possibility of renegotiating agreements on rules, criteria, and conduct based on what took place in the relational sphere during each match. The Elos game put into practice a form of working with permanent renegotiation. The situations that emerged were discussed during the monitoring meetings carried out by the study, where forms of improving the participation of the children in the activities were debated. The issues that emerged, and the details and nuances that the actors had to revisit in order to keep the game going, throughout the process of the study, produced increasingly complex frames of negotiation. This revisitation was also an act of "re-spectate", or an experience of respect.

To describe a situation: In a $2^{\text {nd }}$ grade classroom, during the game, one student remained isolated, apart from his group, without carrying out the activity. He was considered a pupil who had issues that made the execution of activities difficult. A doctor's report attested to cognitive difficulties and a lack of color discrimination. The students and teacher accepted this situation as a given and, during matches, the teacher did not take off points for this student remaining "out of play", which according to the rules would have been a foul. Problematizing this situation during monitoring meetings allowed reflections upon this delicate line between care, guardianship, and undermining. The teacher began to encourage the group to invent ways to include the student in the game. There was a process of renegotiation where the group became responsible for the participation of all, as a rule of the game. During some matches, the group's 


\section{pro.posıções \\ $e$-ISSN 1980-6248}

configuration changed: this student began to sit with the other students around the worksheet they were concentrating on, focused and lively, holding the colored pens that were being used by the team. Later, he also began to color in the drawing made by the group and, at the end of the task, showed it to the others in the room.

The questioning of certain variables and conducts produced during the game's execution (for instance, one student not participating and the group tackling the problem) required space for discussion and analysis, so that the impasses produced in a certain context could be dealt with during the monitoring meetings, which had the purpose of problematizing that which took place in the classroom. The shared monitoring, along with a network for discussions and meetings, formed one of the support pillars of the proposal. In this type of work, a dimension of the collective was questioned. In each of the multiple meeting planes for the program with the school - a plane for each small group of students, the collective of administrators and educators that managed the program, the partnership between health professional and educator, the intersectoral negotiation between primary care center and school in the region, the relationship with institutional partners - there was a permanent negotiation that intensified the capacity for collectivity. Elos worked when it was not reduced to a form of applying a method, and when it was possible to access planes of common experiences.

The singularization of experiences that require permanent renegotiation happens with a collective plane that exceeds the habitual notion of a group of individual units in interaction, pointing to a dimension where the terms "individual" and "social" are produced in relation to, and not as separate entities that act one upon the other. According to Escóssia and Kastrup (2005),

\footnotetext{
The collective actions of a network are defined permanently and locally, based on a game of associations and compositions marked by reciprocity, which involves all the elements of the network (p. 302) ... Contrary to a relationship that takes place based on constituted terms such as in the concept of interaction - the path that presents itself is to conceive a relational plane that produces the terms (p. 302) ... The equivalence between collective and group or sum of people disappears. The collective is impersonal, it is a plane of co-production of individuals and of society (p. 303).
}

The common is not a given: it is a production and requires work, according to Teixeira (2015, p. 31), "understood as a ontocreative human activity: an activity of invention of the self and the world", which updates the matter of "reaching the knowledge of relationships and an art of composition: an art of making community or art of production of the common" (Teixeira, 


\section{pro.posıções \\ $e$-ISSN 1980-6248}

2015, p. 35). We are referring to a common plane where changes and inventions become possible.

By placing under analysis the processes of change in sense, affection, and manners of thinking, Machado (2014, p. 771) highlights the importance of connections, which allow us to visualize "the flow, agency itself, connective energy — and emphasize the need to create derivations in situations that to our understanding are imprisoning existence". The connections permeate the networks. As seen in the cited case, this work of renegotiation in a network increases autonomy and generates change, transformation, and inventions that escape the stereotypes and symptomatic standards, in other words, creating an opening for the emergence of news ways of being. This requires a notion of autonomy that exceeds the individual sphere, although, as noted in the above case, this also brings about a growth in individual autonomy.

For this, we have followed the concept of vital normativity as defined by Canguilhem (2009), combining it with the notion of transversality proposed by Guattari (1985). Vital normativity would be a capability inherent to all living beings for constructing norms of life, understanding norm as relationship. To be alive is to be in a permanent relationship, in a way that, the greater the extent of relationships, the wider the network of dependencies, and the higher the autonomy in living. The notion of transversality proposes a dimension of the collective that exceeds the pair of coordinates - verticality and horizontality — that regulate relationships in the shape of hierarchies and identities. A dynamic dimension that produces a shift, a movement, destabilizing the limits set by a given form of organization and putting into play the indeterminate and that which does not make sense. For Guattari (1985), it is within this zone of indetermination that new possibilities of enunciation emerge. This perspective of autonomy indicates an ethical direction that is open to processes of minority action with an instituting force, which destabilizes given standards a priori.

Autonomy, when understood as a possibility for action by the collective and for broadening normative capabilities in common planes, questions the isolation that educators complained about. Either the proposal develops this autonomy, or the game tends to become set in one form and technique, losing potential and reproducing subjection. By playing, students and teachers are permanently dealing with disparate experiences of exclusion, isolation, cooperation, implication. When meetings are held between educators, professional health partners, and students, in order to think, revise, alter, and experiment forms and manners for 


\section{pro.posıções \\ $e$-ISSN 1980-6248}

http://dx.doi.org/10.1590/1980-6248-2019-0072EN

the common plane, there is a growth of autonomy in the relationships. Inversely, without these spaces there is rigidity, and a polarization of identities and reactive actions. In one $4^{\text {th }}$ grade classroom, an educator found herself facing difficulties, having no partnership with a health interlocutor or with peers at school. There was no space for invention and renegotiation, crucial for fracturing practices. Match after match, she would mark down, for one team, fouls caused by that group's Guardian. Guardians were chosen by teachers from among those who were generally more isolated, and had the tasks of communication between the group and teacher and distribution of materials, among others. This Guardian suffered, however, a growing rejection on behalf of the group, leading to a rupture where he refused to participate with his team and instead carried out the activity alone.

Another problematic situation found space for joint discussion and production in a study group with participating students from a $2^{\text {nd }}$ grade class which was monitored by the teacher and a health partner. The members of one team complained about a student who never executed the activities, although he knew how to, which meant the team was marked with a foul in every match. During a meeting with the group of students in the study, this situation was discussed by the children; the pupil reported that his refusal to carry out the activities was because they were tasks that he already knew how to do, while other members of the team expressed their discomfort due to the fact that he did not fit in with the team, undermining his group. After this experience of sharing and communication, the group's configuration changed. In the last match of the year, the student completed the activity in his notebook, confirming his participation in his pact with his team.

The educators warned of the weight of experience, so that the potential of the Elos game and its differences could be noted. They understood that training should take place over the year, throughout the monitoring process, when situations emerged that had to be problematized. According to Kruppa (2015), this value of the experience could only be accessed by means of joint self-evaluation processes by the teachers. The perspective of the Elos game is of construction as a network, creation of the common, and intensification of the collective, which entailed drawing upon the experience, along with others, when faced with situations that provoked thought. Without training connected to the experience and the shared monitoring, the problematization of the cooperation-exclusion polarity, made evident by the game, had neither place nor interlocution. In this manner, the isolation of educators and the exclusion 


\section{pro.posições \\ $e$-ISSN 1980-6248}

practices persisted: in a $4^{\text {th }}$ grade class where a student diagnosed with autism was removed from the classroom every time Elos was played.

\section{The experience of playing: the implication of oneself and the potential for learning}

The educators paid particular attention to the value of their experience during game practice, and valued the time spent on monitoring, sharing, and training during the process throughout the year, supporting a lasting movement regarding their own selves, a viewing and reviewing of oneself in the act of playing. In this process, the educators were surprised to note changes in their gaze toward the students and their practices. This change in perspective comes close to what Aquino (2009, p. 69) designates as an "ethical-political attitude of placing in check the games of truth and their subjectivation effects, always in action. Instead of dreaming of their disappearance, this is about playing with the least domination possible". The educators pointed out the daily habit of "giving commands", in other words, a certain way of telling students what they had to do, inducing what they should think or do. Differently, the game activity (and its rules) guided the actions of the groups of students and of the teachers. The children found their paths and the teachers observed, which was discomfiting at first for not fitting in with the customary interventions. Observing was an effort: observe what, who? How does one observe? How does one exercise observation? It was necessary to momentarily suspend giving orders, and maintain a time period in which the teachers optimized listening to what the children were bringing, allowing them to position themselves: the time of differentiations and passages. This brings educators the possibility of changes in perspective; when a pupil was no longer visible due to stereotyping, singularities and heterogeneities emerged. In the meetings held with groups of students during the study, they concluded that Elos educated both students and teachers. There were many situations where the students played, generating reprimands from the teachers. One day, after one of these scenes, the teacher reported in the monitoring meeting that when practicing the Elos game she saw herself in many moments as "a shrew" who had no enjoyment of the children's playfulness.

By following the rules and goals of the game, the students exercised a perception of their own selves, their voice, their bodies, their participation, and their conduct towards others, 


\section{pro.posıções \\ $e$-ISSN 1980-6248}

http://dx.doi.org/10.1590/1980-6248-2019-0072EN

something that also took place with the educators. Carrying out the game and its monitoring allowed them to convert from the gaze upon oneself, which for Deleuze (1992, p. 123) is "curving the force, making it affect itself, instead of affecting other forces: a 'fold', according to Foucault, a relationship of force with itself'.

This "fold" process was accompanied by another problem brought up by the game: how to call attention to rule-breaking in the game in a manner that emphasized the rules, and not the person who broke them? The Elos game method recommended that educators use a "neutral tone", and this was discussed by the teachers when they problematized the disciplinary function that prevailed in their speech. Like the students, who needed to observe themselves within the group in order to play, the teachers also needed to self-observe, test, and modulate ways of acting and speaking. In this sense, the Elos game formed that which Vicentin (2016, p. 41) named a "collective protection mechanism", since "the vulnerability and risk that flow through the bodies and the lives of children and youths diminish as collective commitments grow and as the adults increasingly take on more risks, in other words, expanding their margins of implication".

This questioning of "tone of voice" intersected with another reference of conduct: the issue of the habit of correction. This brings up an enormous difficulty: the game gives visibility to an entire corrective machinery that values the repetition of the expected, annulling errant paths upon which a new knowledge might be constructed. In the practice of the game and of the support collectives and partnerships between health and education workers, noting these habits changed the connections of force upon themselves and in the relationships with others. By thinking about these connections in the pedagogic field, Gallo (2006, p. 188) states that "the reciprocity of an ethical action based on a care of oneself and a care of the other, in which the game of construction of freedom can only be played as a collective game, with mutual interactions and relationships, where the actions of some lead to the actions of others". In the study groups, the students referred to this experience within the Elos game as "help", the satisfaction of helping and being helped with the tasks. They reported that in the game they felt cared for and caring. Silva and Freitas (2015) broaden these ethical notions of working on oneself, both for teachers and students, setting them as moral and intellectual resources for dealing with events throughout life. This work with oneself was favored, therefore, by an accompanying foreign gaze during an unprecedented experience: seeing the self as a partner 


\section{pro.posıções \\ $e$-ISSN 1980-6248}

who sees you. The educators lived through this experience within the spaces for sharing, along with the health professionals and their peers.

The act of playing awoke interest, curiosity, and a desire to participate. The children wanted to play more frequently and pressured the teacher for this. In a $3^{\text {rd }}$ grade classroom, a student diagnosed with autism, who habitually did not participate in the activities, got up during an Elos match, registered the activity on the blackboard, and sat back down with her group. Although it fell outside the game rules, her gesture, made during the game, confirmed her interest and desire to play. The autonomy seen in this example stems from the capacity to act and create in connection with the common plane for the game. Playing, as a common sign, creates meanings that allow us to think that, in the act of playing, the sense of inclusion expanded to all students, as defined by David Rodrigues (Sofiato \& Angelucci, 2017):

The inclusive environment is an environment of learning in which it is possible that all the students learn one from another, where all can interact and cooperate in a citizen and ethical manner (p. 291).

... inclusion is a transversal value of schools and should be promoted for all students, whether they are disabled or not (p. 292).

In the research groups with students, the highest potential for Elos was to be a game. Associated with team games and children's play, Elos gathered in itself the attributes of joyful potential. By playing, a learning space was created that destabilized the relational field which produced fatigue and excessive commands in teachers.

We noted three elements that signal that the act of playing raises the potential for learning in school. First, the game produced a shift in the place occupied by students and teachers. The act of playing was a task of teachers and students, a field of negotiations where students grew in autonomy when carrying out the tasks. In this new condition, there was an increase in the possibilities of what the child could do. This potential for internal differentiation was accompanied by feelings verbalized in the meetings with students in the following manner: "I am smarter", "I learn more", "I'm more intelligent", "I'm prepared to go to the third grade", "I know new places and new people".

Another element was the need to appropriate rules in order to play the game, to connect with the experience of it. A Physical Education teacher commented that, in the beginning of his class, the students from the group playing the Elos game valued and better understood 


\section{pro.posıções \\ $e$-ISSN 1980-6248}

instructions given before the start of activities. In the Elos game, the rules of conduct were inscribed in a different register that was not only that of behavior, but of access in the sense of being in the game, of playing as a group.

Lastly, the game demanded the observance of certain attitudes. In the study groups the children characterized Elos as a game in which they could experience relationships of solidarity and shared knowledge: "we gather the players, everyone works together". "The group is very cool, you have to talk, participate, even those who don't like to talk, talk." "When we like doing something, we can help." The communication of points of view and the connection between the differences and heterogeneities became a central feature of the experience. According to Gallo (2012, p. 8), "learning is always meeting with the other, with the different, the invention of new possibilities; learning is the reverse of the reproduction of the same”. Another attitude change referred to the condition of the experience: the students stated that in the Elos game they "had to think, it's slow, calm". "When you speak loudly, it gives you a headache, our ears hurt." "When it gets quieter, it's so good that we all get happy." "The Elos game has concentration." This appreciation of the experience by the students corroborates the analysis that Larrosa Bondía (2002) makes about the condition of an experience in contemporaneity. For an experience to take place, for something to touch us, a gesture of suspension must occur, requiring us to "stop to think, stop to look, stop to listen, think slower, look slower, and listen slower" (Bondía, 2002, p. 19).

The students expressed attitudes and sentiments that related to the joy and well-being of others and of themselves; the game was seen as a space of joy, fun, and laughter that indicated a space-time of the event, in which took place, as stated by Bondía (2002), the art of the encounter; in this case, an encounter that strives for learning.

\section{Final considerations}

This study outlines a plan in which the forms of governing, of guiding conduct, that are present in educational institutions and in the programs implemented within them, tend to reproduce automatisms, stereotypes, and standards that are at odds with a collective plane that is heterogeneous, multiple, and in permanent production of worlds and manners of being. We 


\section{pro.posıções \\ $e$-ISSN 1980-6248}

http://dx.doi.org/10.1590/1980-6248-2019-0072EN

were interested in investigating the processes that destabilized the automatisms relating to situations of isolation, disrespect, and subjection in the field of forces of the daily life of schools, pointed out by the teachers as issues.

The visibility of these processes brings us back to the ethical responsibility of the program in taking care of transformations in the field of forces and of the forces at play in the relationships of the collective and oneself, of students and workers, of health and education. Without being occupied with these transformations, the dispositive is reduced to the application of a disciplinary technology for behavior conditioning. In this article we highlight the meetings, the discussions, and the connections between health and education as elements that support the alteration of the forces at play in a school's daily life. The reproduction of adverse conditions, to be faced, demanded common spaces for negotiation. Schilling and Angelucci (2016, p. 699) discuss the emergence of problems and social conflicts within schools, considering that "people exist in school and the question is how these people negotiate their realities in the sphere of this institution ... in their complex games of reproduction and transformation, of freedom and submission, with spaces and interstices of autonomy".

With an interest in pointing out the possibilities and the dangers in implementing specific programs for complex situations in the areas of health and education, this article reflects upon the field of generation of policies that develop prevention dispositives. By interrogating the forms of governing oneself and others that are produced during the day-to-day of the implemented program, the study highlights that movements of renegotiation, of implication of oneself, and of sharing are crucial in order to turn the biopolitical key in a new direction.

Carvalho (2014) reminds us that, when thinking about processes of deinstitutionalization of education, Foucault points out the need to invent strategies that allow the modification of relationships of force, coordinating them in such a way that this modification embeds itself in reality. It is in this sense that the questions present in the lines of analysis developed indicate the need to inscribe the modifications that refer to practices of sharing which formed the basis for the implementation of the Elos game. Without this inscription, the game would simply become one more methodological material. 


\section{pro.posições \\ $e$-ISSN 1980-6248}

\section{References}

Abramovay, M., \& Castro, M. G. (2005). Drogas nas escolas: versão resumida. (Relatório de Pesquisa/2005), Brasília: Unesco, Rede Pitágoras.

Aquino, J. G., \& Ribeiro, C. R. (2009). Processos de governamentalização e a atualidade educacional: novas modulações normativas. Educação e Realidade, 34(2),1-16.

Bondía, J. L. (2002). Notas sobre a experiência e o saber de experiência. Revista Brasileira de Educaşão, 19, 20-28.

Brasil. Coordenação Nacional de DST/Aids. (2000). Manual do multiplicador: adolescentes. Brasília: Ministério da Saúde.

Canguilhem, G. (2009). O Normal e o Patológico, 6a ed. Rio de Janeiro: Forense Universitária.

Caron, E. (2019). Experimentações intensivas: psicofármacos e producão de si no contemporâneo. (Tese de doutorado) Faculdade de Saúde Pública, Universidade de São Paulo, São Paulo.

Carvalho, A. F. (2014). Foucault e a crítica à institucionalização da Educação: implicações para as artes de governo. Pro-Posições, 25(2), 103-120.

Carvalho, S. R. (2015). Governamentalidade, 'Sociedade Liberal Avançada’ e Saúde: diálogos com Nikolas Rose. Interface, 19(54), 647-58.

Deleuze, G. (1992). Conversações. São Paulo: Editora 34.

Escóssia, L., \& Kastrup, V. (2005). O conceito de coletivo como superação da dicotomia indivíduo-sociedade. Psicologia em Estudo, 10(2), 295-304.

Figueiredo, L. C. M. (2007). A Invenção do Psicológico: quatro séculos de subjetivação, 7a ed. São Paulo: Escuta.

Foucault, M. (1988). O Nascimento da medicina social. In Foucault, M. Microfísica do poder (pp. 79-98). 6a ed. Rio de Janeiro: Graal.

Foucault, M. (2004). Tecnologias de si. Verve, 6, 321-360.

Gallo, S. (2006). Cuidar de si e cuidar do outro. In Kohan, W.O., \& Gondra, J. (Orgs.) Foucault 80 anos (pp. 177-190). Belo Horizonte: Autêntica. 


\section{pro.posıções \\ $e$-ISSN 1980-6248}

Gallo, S. (2012). As múltiplas dimensões do aprender. Congresso de Educação Básica COEB, Florianópolis Recuperado de http://www.pmf.sc.gov.br/arquivos/arquivos/pdf/13_02_2012_10.54.50.a0ac3b8a14 0676ef8ae0dbf32e662762.pdf

Guattari, F. (1985). Revolução molecular: pulsações políticas do desejo, $2^{\mathrm{a}}$ ed. Rio de Janeiro: Brasiliense.

Guerra, G., \& Clark, N. (2010). Da coerção à coesão: Tratamento da dependência de drogas por meio de cuidados em saúde e não da punição. Escritório das Nações Unidas sobre Drogas e Crime. Recuperado de https://www.unodc.org/documents/lpobrazil/noticias/2013/09/Da_coercao_a_coesao_portugues.pdf

Kellam, S. G., Wang, W., Mackenzie, A. C., Brown, C. H., Ompad, D. C., Or, F., ... \& Windham, A. (2014). The Impact of the Good Behavior Game, a Universal ClassroomBased Preventive Intervention in First and Second Grades, on High-Risk Sexual Behaviors and Drug Abuse and Dependence Disorders into Young Adulthood. Prevention Science, 15(1), 6-18.

Kruppa, S. M. P., Caramelo, J., \& Terrasêca, M. (2015). A autoavaliação pode fazer diferença na qualidade da educação: conversando com John MacBeath. Educ. Pesqui, 41(n.spe), 16011615.

Machado, A. M. (2014). Exercer a postura crítica: desafios no estágio em psicologia escolar Psicologia: Ciência e Profissão, 34(3), 760-773.

Machado, L. V., \& Boarini, M. L. (2013). Políticas Sobre Drogas no Brasil: a Estratégia de Redução de Danos. Psicologia: Ciência e Profissão, 33(3), 580-595.

Medeiros, P. F. P., Cruz, J. I., Schneider, D. R., Sanudo, A., \& Sanchez, Z. M. (2016). Process evaluation of the implementation of the Unplugged Program for drug use prevention in Brazilian schools. Substance abuse treatment, prevention, and policy, 11(2). Recuperado em 18 maio 2018, de https://substanceabusepolicy.biomedcentral.com/articles/10.1186/s13011-015-00479

Passos, E., Kastrup, V., \& Escóssia, L. (2009). Pistas do Método da Cartografia: Pesquisa-Intervenção e produção de subjetividade. Porto Alegre: Sulina. 


\section{pro.posıções \\ $e$-ISSN 1980-6248}

Peres, M. G., Grigolo, T. M., \& Schneider, D. R. (2016). Percepções sobre um programa de prevenção ao uso de drogas nas escolas para o desenvolvimento de habilidades de vida. Saúde \& Transformação Social, 6(1), 111-123.

Rose N. (1999). Governing the soul. The shaping of the private self. (2nd ed.) London, UK: Free Association Books.

Schneider, D. R., Pereira, A. P. D., Cruz, J. I.; Strelow, M., Chan, G.; Kurki, A., \& Sanchez, Z. M. (2016). Avaliação da implementação em escolas brasileiras de um programa preventivo para crianças. Psicologia Ciência e Profissão, 36(3), 508-519.

Schilling, F., \& Angelucci, C.B. (2016). Conflitos, violências, injustiças na escola? Caminhos possíveis para uma escola justa. Cadernos de Pesquisa, 46(161), 694-715.

Silva, N. M. A., \& Freitas, A.S. (2015). A ética do cuidado de si no campo pedagógico brasileiro: modos de uso, ressonâncias e desafios. Pro-Posições, 26(1), 217-233.

Sofiato, C. G., \& Angelucci, C. B. (2017). Educação inclusiva e seus desafios: uma conversa com David Rodrigues. Educ. Pesqui., 43(1), 281-295.

Teixeira, R. R. (2015). As dimensões da produção do comum e a saúde. Saúde e Sociedade, 24(1), $27-43$.

United Nations on Drugs and Crime - Unodc (2015). International Standards on Drug Use Prevention.

https://www.unodc.org/documents/prevention/UNODC_2013_2015_international_ standards_on_drug_use_prevention_E.pdf

Vadrucci, S., Vigna-Taglianti, F.D., van der Kreeft, P., Vassara, M., Scatigna, M., Faggiano, F. \& Burkhart, G. (2016). The theoretical model of the school-based prevention program 'Unplugged'. Global health promotion, 23(4), 49-58.

Vicentin, M. C. (2016). Criançar o descriançável. In Caderno de debates do Naapa: questões do cotidiano escolar (pp. 35-42). São Paulo: Secretaria Municipal de Educação/Coped.

Zorzanelli, R. T., Ortega, F., \& Bezerra Júnior, B. (2014). Um panorama sobre as variações em torno do conceito de medicalização entre 1950-2010. Cien Saude Colet, 19(6):1859-1868. 


\section{pro.posições \\ $e$-ISSN 1980-6248}

\section{Submission data:}

Submitted for evaluation on $18^{\text {th }}$ May de 2019; revised on 21 th February de 2020; accepted for publication on 30 April, 2020.

\section{Author's contact:}

Universidade de São Paulo, Faculdade de Saúde Pública, Práticas de Saúde, Av. Dr. Amaldo 715, São Paulo, SP, Brasil. 03178-200 